\title{
Effects of D-allose in combination with docetaxel in human head and neck cancer cells
}

\author{
KANAKO INDO $^{1}$, HIROSHI HOSHIKAWA ${ }^{1}$, KAZUYO KAMITORI $^{2}$, FUMINORI YAMAGUCHI $^{2}$, \\ TERUSIGE MORI ${ }^{1}$, MASAAKI TOKUDA ${ }^{2}$ and NOZOMU MORI ${ }^{1}$ \\ Departments of ${ }^{1}$ Otolaryngology and ${ }^{2}$ Cell Physiology, Faculty of Medicine, \\ Kagawa University, Kagawa 761-0793, Japan
}

Received May 8, 2014; Accepted July 2, 2014

DOI: $10.3892 / \mathrm{ijo} .2014 .2590$

\begin{abstract}
In this study we investigated the combined effects of docetaxel and D-allose in HSC3 human oral carcinoma cells. The dose enhancement ratios at the $25 \%$ survival level were 1.3 and 1.71 for combined treatment with 10 or $25 \mathrm{mM}$ D-allose, respectively. Apoptosis was significantly increased by addition of $\mathrm{D}$-allose. Additionally, a synchronous increase in the $\mathrm{G}_{2} / \mathrm{M}$-phase population was observed after docetaxel plus D-allose treatment. In vivo experiments revealed that docetaxel plus D-allose was more effective than either agent alone. Thus, D-allose enhanced the anticancer effects of docetaxel, and combined treatment may be useful to achieve clinical efficacy with reduced toxicity.
\end{abstract}

\section{Introduction}

Docetaxel, the most potent taxane, is derived from extracts of European yew needles. Docetaxel has been shown to have significant antitumor activity. The main mechanism of action is through stabilization of tubulin, arresting cells in the $G_{2} / M$ phase of the cell cycle (1). In head and neck cancer patients, docetaxel is now widely applied as first- and secondline induction chemotherapy or used in combination with other anticancer drugs or radiation (2-7). However, some patients develop resistance to docetaxel. Although the causes and mechanisms of docetaxel resistance are still unknown, activation of the redox system is thought to be involved (8). Thioredoxin (TRX), a small redox-active multifunctional protein, acts as a potent antioxidant and redox regulator in signal transduction (9). TRX has been reported to be overexpressed in various types of cancers (10-12) and its overexpression is associated with a poor prognosis in patients $(13,14)$. Indeed, Kim et al $(15)$

Correspondence to: Dr Kanako Indo, Department of Otolaryngology, Faculty of Medicine, Kagawa University, 1750-1 Ikenobe, Miki-cho, Kita-gun, Kagawa 761-0793, Japan

E-mail:kanakana@med.kagawa-u.ac.jp

Key words: D-allose, docetaxel, head and neck cancer, anticancer effects reported that breast tumors with high TRX expression show a significantly lower response rate to docetaxel treatment than those with low TRX expression.

$\mathrm{D}$-allose is a rare sugar that is found only in very small quantities in nature. In recent studies, we reported that D-allose inhibited the growth of head and neck cancer cells by inducing of cell cycle arrest, apoptosis and competition with glucose uptake (16). In addition, D-allose stimulates the overexpression of TRX-interacting protein (TXNIP) and enhances the effects of radiation (17). TXNIP is known to interact with TRX and is involved in the regulation of the cellular redox state (18). Moreover, the TXNIP gene is a tumor suppressor (19) and metastasis suppressor (20) and its expression is lower in various cancer cells when compared to normal cells (21-23). Therefore, we speculated that the induction of TXNIP expression by D-allose treatment may enhance the anticancer effects of docetaxel.

In the present study, we evaluated the combined effects and mechanisms of docetaxel and D-allose in head and neck cancer in vitro and in vivo.

\section{Materials and methods}

Cell culture. The human head and neck carcinoma cell line HSC3 (tongue carcinoma) was obtained from the Health Science Research Resources Bank, Osaka, Japan. HSC3 cells were cultured at $37^{\circ} \mathrm{C}$ in an atmosphere containing $5 \% \mathrm{CO}_{2}$ in Eagle's minimal essential medium (EMEM), $10 \%$ heat-inactivated fetal bovine calf serum and $1 \%$ penicillinstreptomycin.

Determination of cell survival. D-allose was kindly supplied by Dr K. Izumori at the Department of Biochemistry and Food Science, Faculty of Agriculture, Kagawa University, Kagawa, Japan. Docetaxel was obtained from Sanofi (Paris, France) and stored in frozen aliquots. Before use, docetaxel was thawed and diluted to the desired concentrations in the cell culture medium. The growth inhibitory effects of docetaxel plus D-allose were compared with those of docetaxel or D-allose alone. The cells were seeded in 96-well plates at a density of $2.5 \times 10^{3}$ cells $/ 100 \mu \mathrm{l}(\mathrm{n}=5$ wells/treatment) and were cultured for $24 \mathrm{~h}$. Medium was then removed, and fresh medium containing $0.1 \mathrm{ng} / \mathrm{ml}$ docetaxel, $10 \mathrm{mM}$ D-allose or $0.1 \mathrm{ng} / \mathrm{ml}$ 
docetaxel plus $10 \mathrm{mM}$ D-allose were added. Cells were incubated for an additional 24-96 h. The net number of viable cells was then determined using a Cell Counting Kit-8 (CCK-8; Dojindo Laboratories, Kumamoto, Japan) according to the manufacturer's instructions. The absorbance was measured by a microplate reader at $450 \mathrm{~nm}$ after $2 \mathrm{~h}$ of incubation.

To investigate the enhancement of docetaxel-dependent anticancer effects by D-allose, $5 \times 10^{3}$ cells $/ 500 \mu 1$ were plated into 6-well plates and cultured for $24 \mathrm{~h}$ ( $\mathrm{n}=3$ wells/treatment). The cells were treated with 0,10 or $25 \mathrm{mM}$ D-allose and various concentrations of docetaxel and were incubated at $37^{\circ} \mathrm{C}$ for $96 \mathrm{~h}$. Colonies were fixed with $3: 1$ methanol/acetic acid and stained with $0.5 \%$ crystal violet in methanol. Colonies were counted under a microscope, with a cut-off of 50 viable cells. The survival fraction was calculated as (mean colonies)/ (cells inoculated) $x$ (plating efficiency). The docetaxel dose enhancement ratio (DER) was calculated as the dose (ng/ml) for docetaxel alone divided by the dose $(\mathrm{ng} / \mathrm{ml})$ for docetaxel plus D-allose for a survival fraction of 0.25 .

For three-dimensional (3D) culture experiments, the 3D culture BME cell proliferation assay (Trevigen, Gaithersburg, MD, USA) was used. Each well of a 96-well plate was coated with $35 \mu \mathrm{l}$ of 3D Culture BME, and plates were then incubated at $37^{\circ} \mathrm{C}$ for $1 \mathrm{~h}$ to promote gel formation. Cells were then seeded in the coated 96-well plates at a density of $5 \times 10^{3}$ cells per $100 \mu \mathrm{l}$ and cultured for $48 \mathrm{~h}$. After the establishment of 3D structures, $100 \mu \mathrm{l}$ of fresh medium containing $0.1 \mathrm{ng} / \mathrm{ml}$ docetaxel, $25 \mathrm{mM}$ D-allose or $0.1 \mathrm{ng} / \mathrm{ml}$ docetaxel plus $25 \mathrm{mM}$ D-allose was added. Cells were then incubated at $37^{\circ} \mathrm{C}$ for an additional 5 days. Colonies growing $>5$ fold were scored as survivors. Error bars indicate the standard deviation calculated after pooling the results of 3 independent experiments.

Measurement of apoptosis. TUNEL assays were performed using the Apoptosis Detection System Fluorescein kit (Promega, Madison, WI, USA). Briefly, treated HSC-3 cells were spread on a poly-l-lysine slide (Sigma, St. Louis, MO, USA), fixed with $4 \%$ paraformaldehyde and permeabilized with $0.2 \%$ Triton X-100. Cells were incubated in $50 \mu \mathrm{l}$ TdT incubation buffer [nucleotide mix (fluorescein-12-dUTP) and TdT enzyme prepared according to the manufacturer's protocol] for $60 \mathrm{~min}$ at $37^{\circ} \mathrm{C}$ in a humidified chamber. The reaction was terminated by washing the cells in $2 \mathrm{X}$ SSC followed by 2 washes in PBS. Cells were counterstained with $1 \mu \mathrm{g} / \mathrm{ml}$ propidium iodide and then washed in distilled water. Staining was observed under a fluorescence microscope. Green fluorescence indicated DNA fragmentation due to fluorescein12-dUTP labeling. For each experimental time point, 10 fields, each containing 100 cells, were scored for the appearance of apoptosis; two chambers were scored in this manner for each time point.

Cell cycle analysis. Flow cytometry was performed using a FACSEpics XL flow cytometer (Beckman Coulter, Fullerton, CA, USA). Cells were washed twice with PBS, fixed in $1 \mathrm{ml}$ of $70 \%$ ethanol for $2 \mathrm{~h}$ at $4^{\circ} \mathrm{C}$, treated with $200 \mathrm{~g}$ RNase A, and stained with $50 \mu \mathrm{g}$ propidium iodide. Cell cycle distribution was analyzed using System II software (Beckman Coulter).
Analysis of mRNA expression. To investigate the effects of docetaxel, D-allose and docetaxel plus D-allose on the expression of TXNIP and TRX transcripts, cells were cultured in 6-cm dishes with $0.1 \mathrm{ng} / \mathrm{ml}$ docetaxel, $25 \mathrm{mM}$ D-allose or $0.1 \mathrm{ng} / \mathrm{ml}$ docetaxel plus $25 \mathrm{mM}$ D-allose and incubated for an additional $24 \mathrm{~h}$. Real-time polymerase chain reaction (PCR) was carried out using TaqMan gene expression assay primers and an ABI7700 real-time PCR system. Each reaction was performed in duplicate. The GAPDH gene was used to normalize expression across assays and runs, and a threshold value $(\mathrm{Ct})$ for each sample was used to determine the expression level of the gene.

Western blot analysis. After treatment with $0.1 \mathrm{ng} / \mathrm{ml}$ docetaxel, $25 \mathrm{mM}$ D-allose or $0.1 \mathrm{ng} / \mathrm{ml}$ docetaxel plus $25 \mathrm{mM}$ D-allose for $24 \mathrm{~h}$, cells were scraped into lysis buffer (1\% NP40, $150 \mathrm{mM}$ $\mathrm{NaCl}, 50 \mathrm{mM} \mathrm{NaF}, 20 \mathrm{mM}$ Tris- $\mathrm{HCl}, \mathrm{pH}$ 7.5, $1 \mathrm{mM} \mathrm{Na} \mathrm{VO}_{4}$, $10 \mu \mathrm{M} \mathrm{Na}_{2} \mathrm{MnO}_{4}, 1 \mathrm{mM}$ PMSF, $10 \mu \mathrm{g} / \mathrm{ml}$ leupeptin, $1 \%$ aporotinin) with protease inhibitors and sonicated. Samples were centrifuged for $10 \mathrm{~min}$ at 14,000 rpm and supernatants were collected. For western blot analyses, proteins were separated on $10 \%$ SDS-PAGE gels, transferred to nitrocellulose membranes, blocked with $5 \%(\mathrm{w} / \mathrm{v})$ non-fat dried milk in PBS and incubated with anti-TXNIP (MBL, Nagoya, Japan), anti-TRX (MBL) or anti- $\beta$-actin antibodies (Sigma). Membranes were probed with a horseradish peroxidase-conjugated anti-mouse IgG (Amersham, Tokyo, Japan), and signals were detected with an enhanced chemiluminescence system (Amersham).

Detection of reactive oxygen species (ROS) detection. Intracellular ROS generation was measured using the Total ROS Detection kit (Enzo Life Sciences, Plymouth Meeting, PA, USA) according to the manufacturer's instructions. Cells were incubated with dye from the kit at $37^{\circ} \mathrm{C}$ for $1 \mathrm{~h}$. Immediately after staining, the cells were analyzed using a fluorescence microscope (Olympus BX-51, Tokyo, Japan) equipped with a standard green filter $(490 / 525 \mathrm{~nm})$.

In vivo xenograft experiment. HSC3 cells were used in a xenograft model with female athymic nude mice (BALB/c nu/nu, 5-6 weeks old). A suspension of $1 \times 10^{6}$ cells in $0.1 \mathrm{ml}$ volume was injected subcutaneously into the posterior flanks of mice using a 1-cc syringe with a $27-G$ needle. Tumors were grown for 14 days until attaining an average size of $100-150 \mathrm{~mm}^{3}$ (Day 0). Treatment groups were as follows: a) control; b) treatment with $500 \mathrm{mM}$ D-allose; c) $12 \mathrm{mg} / \mathrm{kg}$ docetaxel; and d) $12 \mathrm{mg} / \mathrm{kg}$ docetaxel plus $500 \mathrm{mM}$ D-allose. Each treatment group contained 6 mice. D-allose was prepared by dissolving compound in normal saline to reach a final concentration of $500 \mathrm{mM}$ and aliquots $(0.2 \mathrm{ml})$ were injected around tumors 5 times/week for 3 weeks. Docetaxel was diluted in normal saline to reach a final concentration of $1 \mathrm{mg} / \mathrm{ml}$, and aliquots $(0.2 \mathrm{ml})$ were administered by intraperitoneal injection on Days 0 and 7. Mice from the control group were injected with $0.2 \mathrm{ml}$ normal saline at the same time points. This research was approved by the Animal Care and Use Committee of Kagawa University.

Statistical analysis. Comparisons between groups were carried out using the Student's t-test. Differences with P-values of $<0.05$ were considered statistically significant. 


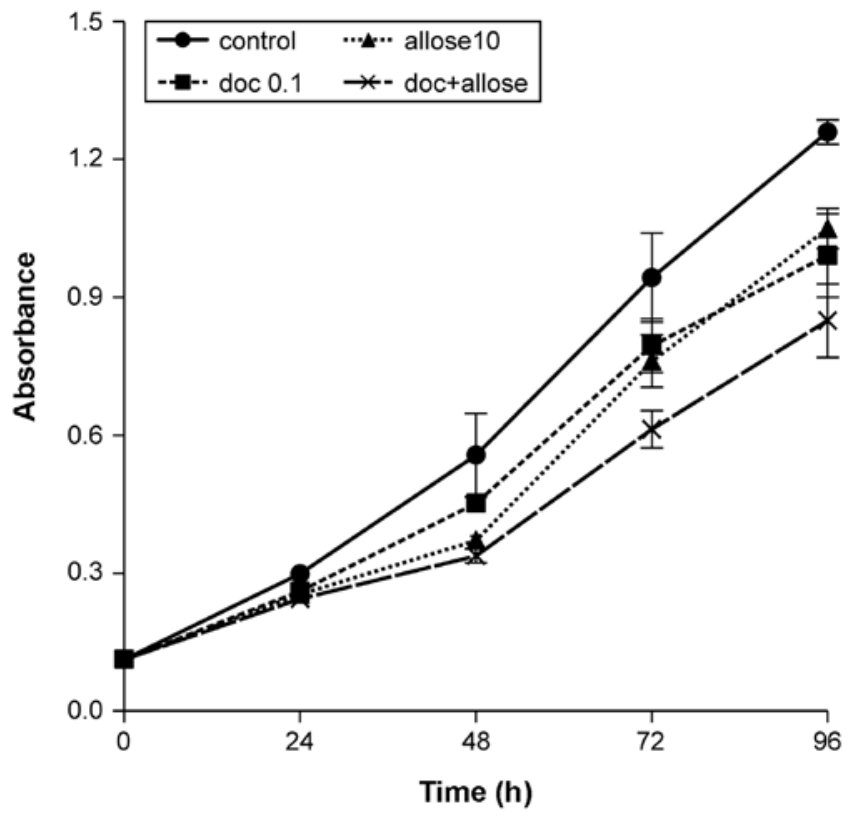

Figure 1. CCK-8 assay to analyze the effects of docetaxel, D-allose and docetaxel plus D-allose on HSC3 cells. Cells were seeded in 96-well plates. After $24 \mathrm{~h}, 0.1 \mathrm{ng} / \mathrm{ml}$ docetaxel, $10 \mathrm{mM}$ D-allose or $0.1 \mathrm{ng} / \mathrm{ml}$ docetaxel + $10 \mathrm{mM}$ D-allose were added. Cells were incubated for an additional 24-96 h.

\section{Results}

Effects of D-allose in combination with docetaxel. Ninety-six hours after treatment with docetaxel, D-allose or docetaxel plus D-allose, growth of HSC3 cells was decreased to 78.7, 83.3 and $67.4 \%$ that of the control, respectively. The combination of docetaxel plus D-allose significantly inhibited cell proliferation when compared to treatment with docetaxel or D-allose alone $(\mathrm{P}<0.001$ and $\mathrm{P}<0.001$, respectively; Fig. 1$)$. As shown in Fig. 2, treatment of cells with $10 \mathrm{mM}$ D-allose resulted in a docetaxel dose enhancement ratio (DER) of 1.3, while treatment with $25 \mathrm{mM}$ D-allose resulted in a DER of 1.71. Analysis of the morphology and growth of cells in 3D cultures, as shown in Fig. 3, revealed that treatment with docetaxel alone, D-allose alone or docetaxel plus D-allose reduced cell survival to 78, 49 and $28 \%$ that of the control group, respectively. Moreover, the combination of docetaxel and D-allose also induced the highest percentage of apoptosis in comparison to either docetaxel alone or D-allose alone $(\mathrm{P}<0.0001$; Table I).

Modification of the cell cycle. Cell cycle modification by docetaxel and D-allose treatment was analyzed by flow cytometry. Accumulation of cells in the $G_{1}$ phase of the cell cycle was significantly decreased after treatment with docetaxel alone, D-allose alone or docetaxel plus D-allose as compared to that of control group. Although the $\mathrm{G}_{2} / \mathrm{M}$-phase cell populations tended to increase after treatment, no significant differences were found (Fig. 4).

Regulation of $m R N A$ and protein expression. The mRNA expression of TXNIP was markedly increased in HSC3 cells following treatment with D-allose. Additionally, the expression of TXNIP mRNA was enhanced after treatment with the

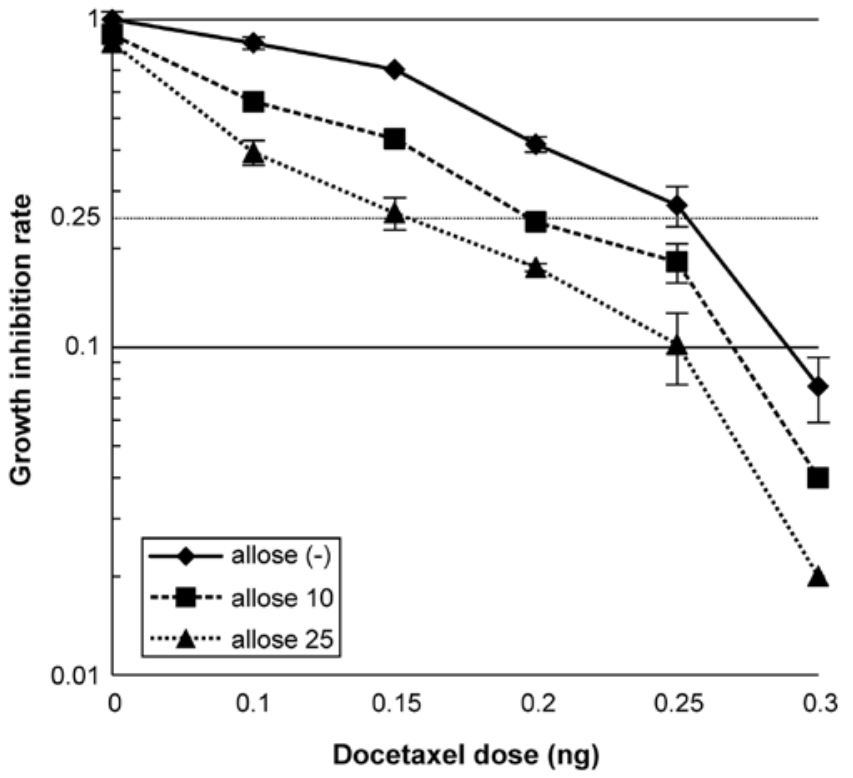

Figure 2. The combined effects of docetaxel and D-allose on the survival of HSC 3 cells, based on the clonogenic assay. Cells were incubated with 0,10 or $25 \mathrm{mM}$ D-allose and various concentrations of docetaxel. Colonies were counted, and growth inhibition curves were constructed. The dose enhancement ratio (DER) was calculated as docetaxel alone divided by docetaxel plus D-allose for a survival fraction of 0.25 .

Table I. Docetaxel dose enhancement ratios and percent apoptosis induced by each treatment.

\begin{tabular}{lcc}
\hline Treatment & Ratio to docetaxel & \% Apoptosis \\
\hline No treatment & 0.78 & $0.55 \pm 0.1$ \\
Docetaxel & 1.00 & $1.71 \pm 0.22$ \\
Allose & 1.58 & $1.22 \pm 0.27$ \\
Docetaxel + allose & 2.81 & $4.25 \pm 0.54$ \\
\hline
\end{tabular}

combination of docetaxel plus D-allose treatment, while no significant increase was observed following treatment with docetaxel alone. Although the mRNA expression of $T R X$ was increased by docetaxel treatment, combined treatment with D-allose and docetaxel significantly suppressed the expression of TRX mRNA (Fig. 5).

TXNIP and TRX protein levels were also evaluated by western blot analysis (Fig. 6). The expression of TNNIP was significantly increased by D-allose treatment, while docetaxel had no effect on TXNIP expression. Although no apparent changes were observed by docetaxel plus D-allose treatment, the protein expression levels of TXNIP and TRX were comparable to the expression levels of their corresponding genes.

Effects of docetaxel and D-allose on ROS production. The intracellular ROS levels following treatment with D-allose were the same as those of the positive control. No excitation emission was observed by exposure to docetaxel in the HSC3 cells. Compared with docetaxel treatment alone, the addition of D-allose induced ROS generation (Fig. 7). 

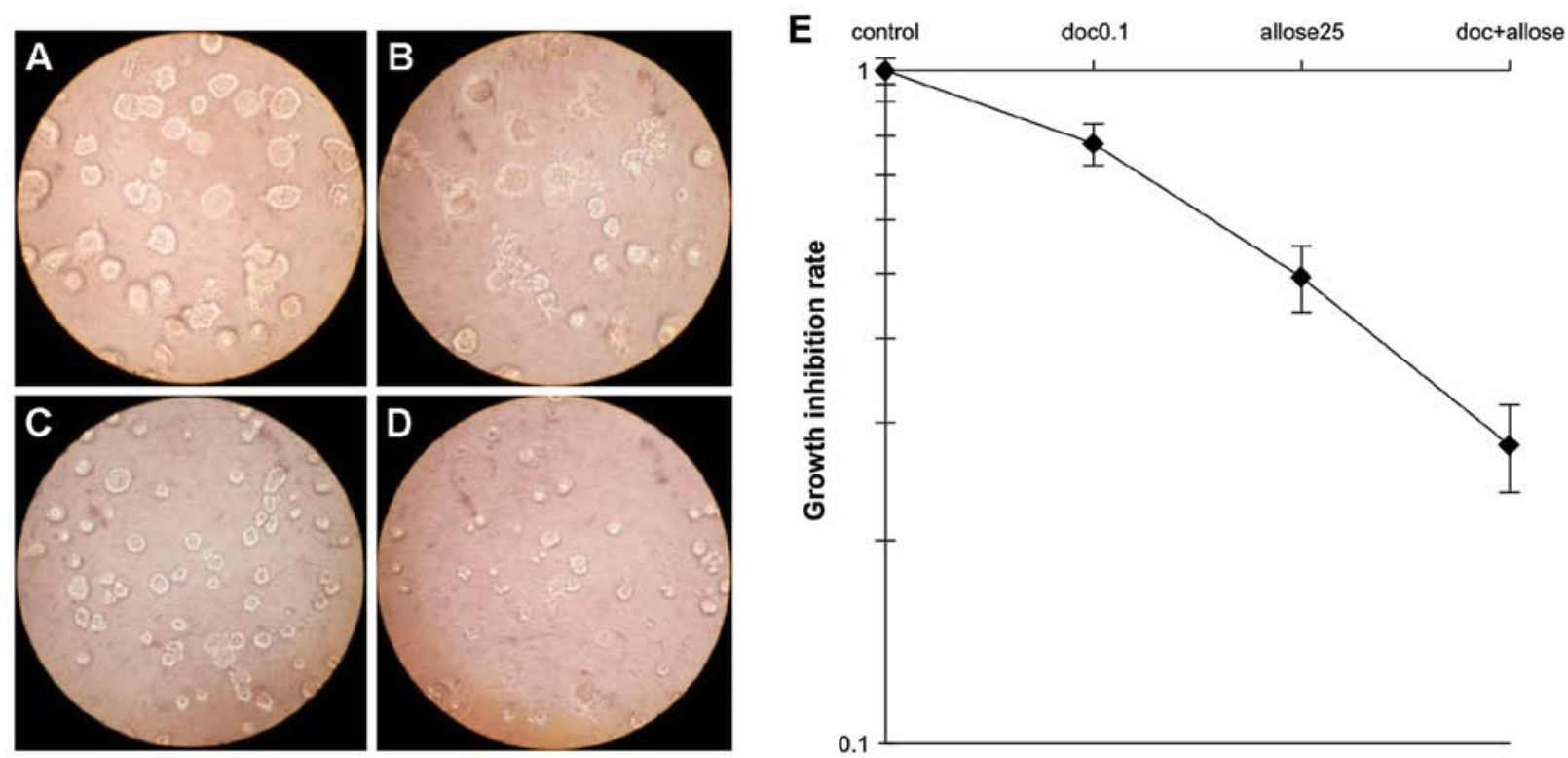

Figure 3. The cell morphology of 3D cultures. (A) Control (no treatment) cells 7 days after the establishment of colonies. (B) Docetaxel (0.1 ng/ml)-treated cells. (C) D-allose (25 mM)-treated cells. (D) Docetaxel plus D-allose-treated cells on 3D cell culture. (E) The growth inhibition of cells exposed to docetaxel alone, D-allose alone or docetaxel plus D-allose were 78,49 and $28 \%$, respectively.

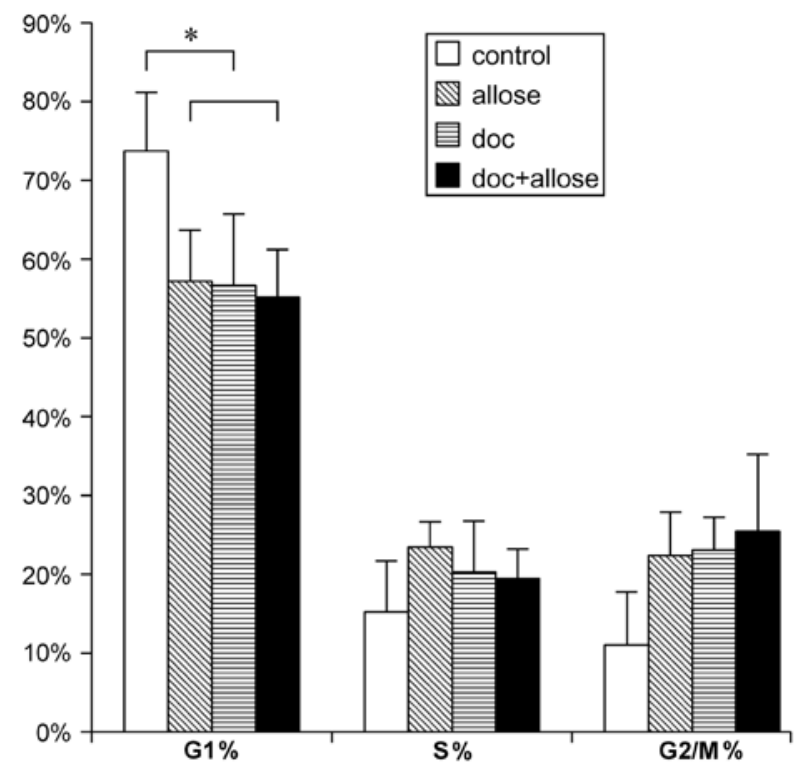

Figure 4. Cell cycle modification of HSC3 cells after treatment. All treatments tended to increase the $\mathrm{G}_{2} / \mathrm{M}$-phase cell population and significantly decreased the $\mathrm{G}_{1}$-phase cell population. " $\mathrm{P}<0.05$.

Effects of D-allose on cell proliferation in vivo. Results of tumor growth assays in vivo are presented in Fig. 8. Administration of $500 \mathrm{mM}$ D-allose for 3 weeks resulted in a significant inhibition of tumor growth compared with that of the control group at Day $20(\mathrm{p}<0.005)$. Moreover, docetaxel treatment also strongly inhibited tumor growth, and combined treatment with D-allose and docetaxel markedly reduced tumor volumes compared to tumor volumes at the beginning of the treatment. No significant tissue damage (such as skin erythema or inflammation) was observed in the treatment groups.

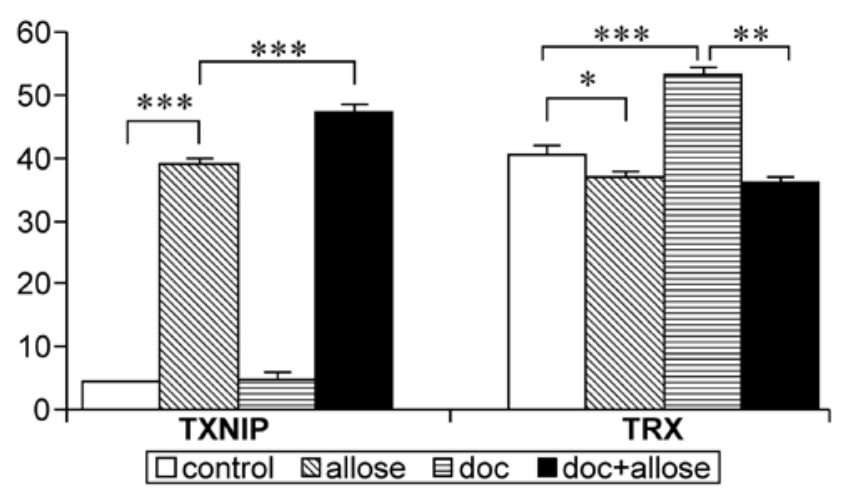

Figure 5. Changes in mRNA expression after treatment with docetaxel, D-allose or docetaxel plus D-allose. Combined treatment with D-allose significantly increased TXNIP mRNA expression and suppressed TRX mRNA expression. ${ }^{*} \mathrm{P}<0.05,{ }^{* *} \mathrm{P}<0.001,{ }^{* * * *} \mathrm{P}<0.0001$.

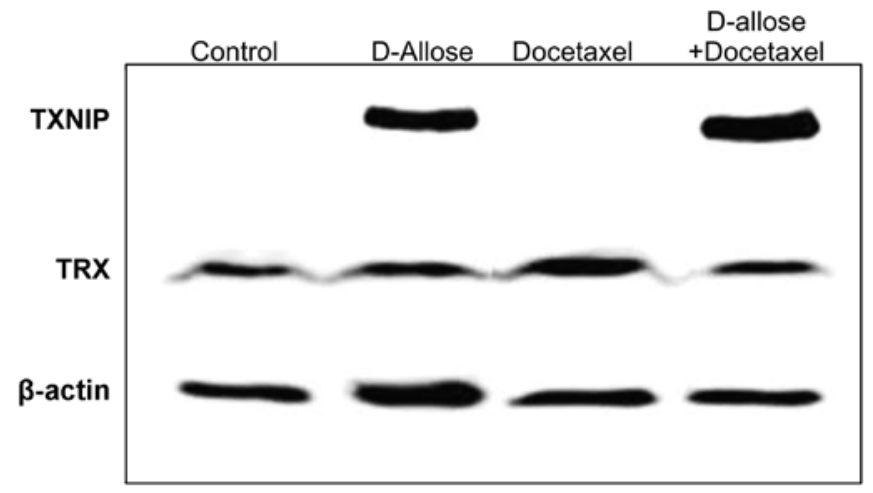

Figure 6. The protein levels of TXNIP and TRX were evaluated $24 \mathrm{~h}$ after the treatment. TXNIP expressions were increased by $\mathrm{D}$-allose alone and docetaxel plus D-allose treatment. Combined use of D-allose seemed to decrease the expression of TRX in comparison to docetaxel alone. 


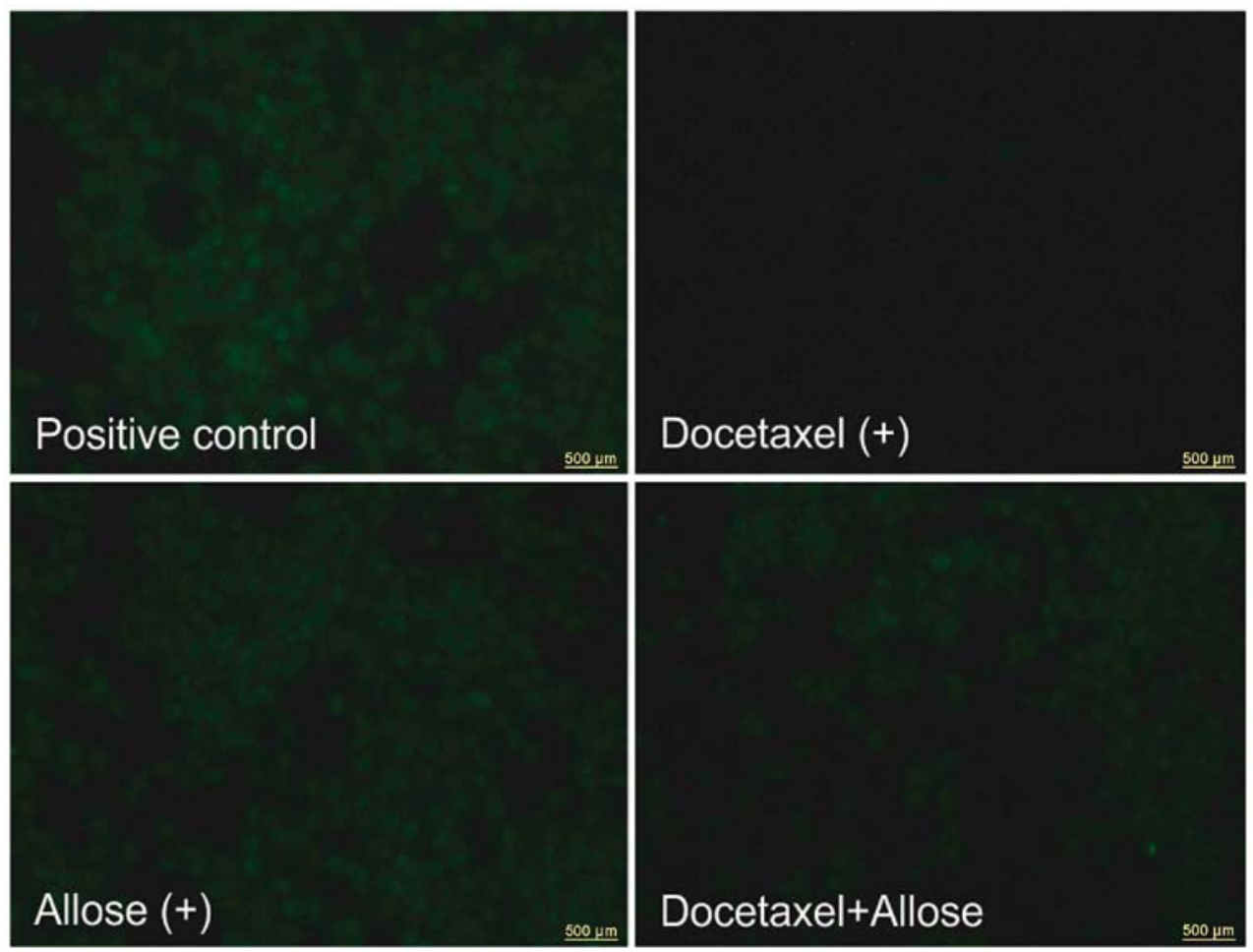

Figure 7. ROS induction was observed by fluorescence microscopy. No staining was observed with docetaxel treatment. The staining under docetaxel was reversed with D-allose treatment.
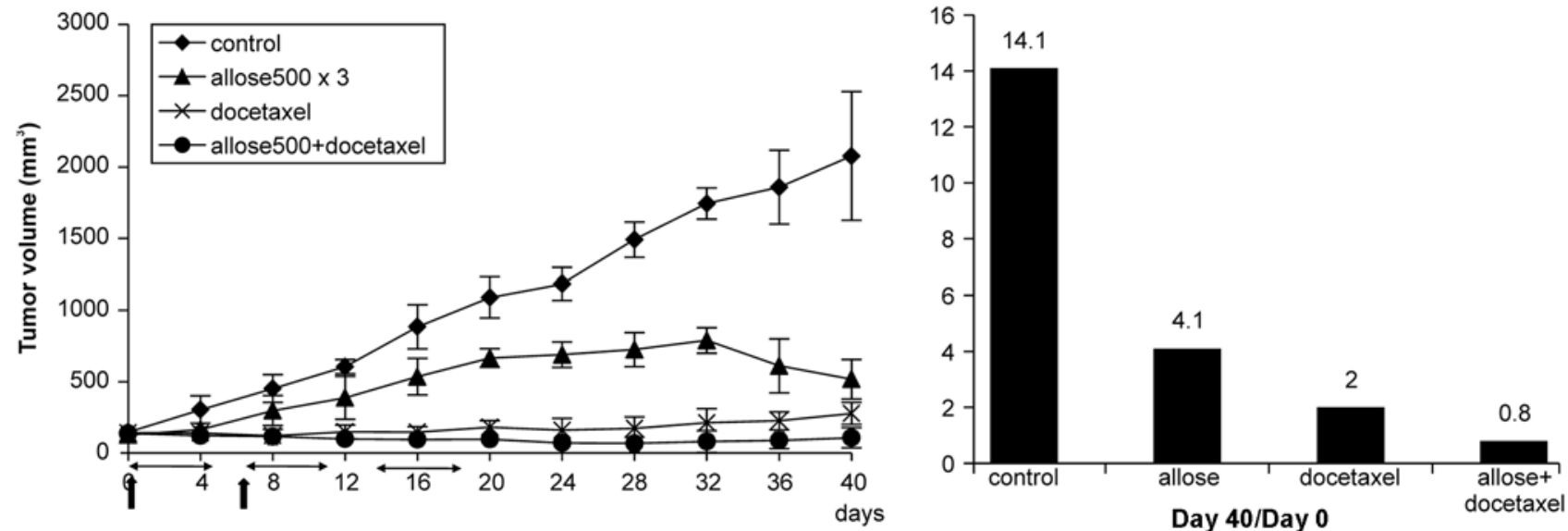

Figure 8. The effects of docetaxel and D-allose on the growth of HSC3 cancer xenografts in nude mice. D-allose was injected around tumors 5 times/week (double-sided arrows). Docetaxel was injected intraperitoneally at Days 0 and 7 (bold arrows).

\section{Discussion}

Docetaxel is a common anticancer drug used in a variety of cancers. In this study, we investigated whether $\mathrm{D}$-allose, a rare sugar that possesses diverse biological effects in cells, could enhance the anticancer effects of docetaxel in head and neck cancer cells. Indeed, our results supported that combined treatment with D-allose plus docetaxel inhibited cell growth and survival to a greater extent than treatment with either compound alone.

The results of the present study showed that docetaxel treatment induced $\mathrm{G}_{2} / \mathrm{M}$-phase cell cycle arrest and enhanced activation of the apoptotic pathway in head and neck cancer cells. Stabilization of microtubules by taxanes results in phosphorylation and inactivation of Bcl-2, leading to increases in Bax levels and a consequent increase in apoptosis (24). Naha et al (25) reported that $\mathrm{D}$-allose induces apoptosis by altering the expression of $\mathrm{Bcl}-2 / \mathrm{Bax}$. In a previous study and in the present study, we clarified that D-allose modulates cell cycle regulatory proteins, $\mathrm{G}_{2} / \mathrm{M}$ cell cycle arrest and apoptosis. These results suggested that the induction of $\mathrm{G}_{2} / \mathrm{M}$ cell arrest and enhancement of the apoptotic pathway by combined treatment of docetaxel plus D-allose promoted the inhibition of cell growth. 
TRX expression has been shown to be increased after docetaxel therapy and is thought to protect cells against docetaxel (14). Therefore, tumors showing increased TRX expression in response to docetaxel are expected to be more resistant to docetaxel than those showing no increase in TRX. Consistent with this, we observed an increase in $T R X$ mRNA expression following docetaxel treatment, without an apparent increase in the generation of ROS. Thus, cancer cells may prevent ROS generation by upregulation of TRX expression. On the other hand, combined use of D-allose and docetaxel resulted in upregulation of TXNIP expression and downregulation of TRX expression compared to treatment with docetaxel alone. These results suggested that induction of TXNIP and suppression in TRX following D-allose treatment may prevent HSC3 cells from becoming resistant to docetaxel.

The radiosensitizing potential of docetaxel has been explored in vitro, in vivo and in clinical trials $(5,6,26,27)$. However, several reports have shown that docetaxel resistance depends on redox regulation, as mediated by increased expression of TRX and a reduction in ROS generation (28). Khan and Ludueña (29) have shown that TRX can reduce a disulfide bridge within the tubulin dimer and inhibit microtubule assembly in vitro. These antioxidant molecules are also thought to contribute to radiation resistance (30-33). Therefore, regulation of the redox state is one of the key mechanisms maintaining radiosensitivity. Recently, we demonstrated that the induction of TXNIP by D-allose can enhance the effects of radiation by increasing both the intracellular ROS level and radiation-induced apoptosis (17). In addition, if D-allose inhibits the attenuation of docetaxel toxicity in cancer cells, we can expect to observe highly enhanced effects by a 3-drug combined therapy.

Docetaxel should be administered $24 \mathrm{~h}$ before irradiation to achieve optimal enhancement of the effects of radiation (27). This is because accumulation in the radiosensitive phase of the cell cycle, i.e., the $\mathrm{G}_{2} / \mathrm{M}$ phase, is most likely observed after $24 \mathrm{~h}$ with docetaxel administration. However, one report demonstrated that preradiation in head and neck cancer cells significantly enhanced docetaxel cytotoxicity by arresting cells in the S phase (34). They concluded that irradiation followed by docetaxel may be the most effective sequence for head and neck cancer therapy. On the other hand, overexpression of TXNIP occurs at $6 \mathrm{~h}$ after D-allose treatment and persists for 24-48 $\mathrm{h}$ after treatment (35). Further studies are needed to clarify the most effective sequence of combined treatment with docetaxel, D-allose and irradiation.

In the present study, our in vivo experiment revealed that $500 \mathrm{mM}$ D-allose injection for 3 weeks prolonged the tumorsuppressive effect after D-allose treatment was completed. In our previous study, tumor regrowth was observed after the completion of D-allose administration for 2 weeks (36). These results suggested that the dosing period may be more important than the application of high doses of D-allose. Tumor volumes in the docetaxel treatment group doubled at 40 days after the initiation of treatment, while those in the control group grew up to 14 times their original size. Moreover, tumor volumes in the combined treatment group were markedly smaller than those at the initiation of treatment. These results suggested that D-allose treatment enhanced the anticancer effects of docetaxel and may reduce the side effects of the chemotherapeutic drug by reducing the total dose of docetaxel required. Major toxicities of docetaxel are neutropenia, mucositis, peripheral neuropathy and pulmonary disorders (37). Concurrent radiation therapy may increase docetaxel toxicity. In particular, radiation-induced mucositis can result in interruption of radiation therapy. However, some reports have shown that D-allose protects the retina and neurons against ischemia-induced damage by attenuating oxidative stress $(38,39)$. It is unknown whether such contradictory responses occur in normal tissue and malignant tumors. However, combined treatment with D-allose may be helpful to prevent radiation-induced mucositis if D-allose suppresses oxidative stress in normal mucosa surrounding the tumor. The mechanism of the redox regulation in normal mucosa by D-allose remains to be elucidated. Further studies are needed to evaluate whether D-allose acts as an antioxidant to protect against radiation and anticancer drugs in normal mucosa.

In conclusion, D-allose enhanced the anticancer effects of docetaxel by inducing changes in the cell cycle and stimulation of apoptotic pathways. Control of the redox state by D-allose may strengthen the radiosensitivity of docetaxel.

\section{Acknowledgements}

This study was supported in part by a Grant-in-Aid for General Scientific Research (Grant 20592019) from the Ministry of Education, Culture, Sports, Science and Technology, Japan.

\section{References}

1. Schiff PB and Horwitz SB: Taxol stabilizes microtubules in mouse fibroblast cells. Proc Natl Acad Sci USA 77: 1561-1565, 1980.

2. Catimel G, Verweij J, Mattijssen V, Hanauske A, Piccart M, Wanders J, Franklin H, Le Bail N, Clavel M and Kaye SB: Docetaxel (taxotere): an active drug for the treatment of patients with advanced squamous cell carcinoma of the head and neck. Ann Oncol 5: 533-537, 1994.

3. Dreyfuss AI, Clark JR, Norris CM, Rossi RM, Lucarini JW, Busse PM, Poulin MD, Thornhill L, Costello R and Posner MR: Docetaxel: an active drug for squamous cell carcinoma of the head and neck. J Clin Oncol 14: 1672-1678, 1996.

4. Baur M, Kienzer HR, Schweiger J, DeSantis M, Gerber E, Pont J, Hudec M, Schratter-Sehn AU, Wicke W and Dittrich C: Docetaxel/cisplatin as first-line chemotherapy in patients with head and neck carcinoma: a phase II trial. Cancer 94: 2953-29582, 2002.

5. Tishler RB, Posner MR, Norris CM Jr, Mahadevan A, Sullivan C, Goguen L, Wirth LJ, Costello R, Case M, Stowell S, Sammartino D, Busse PM and Haddad RI: Concurrent weekly docetaxel and concomitant boost radiation therapy in the treatment of locally advanced squamous cell cancer of the head and neck. Int J Radiat Oncol Biol Phys 15: 1036-1044, 2006.

6. Katori H, Tsukuda M and Watai K: Comparison of hyperfractionation and conventional fractionation radiotherapy with concurrent docetaxel, cisplatin and 5-fluorouracil (TPF) chemotherapy in patients with locally advanced squamous cell carcinoma of the head and neck (SCCHN). Cancer Chemother Pharmacol 60: 399-406, 2007.

7. Lorch JH, Goloubeva O, Haddad RI, Cullen K, Sarlis N, Tishler R, Tan M, Fasciano J, Sammartino DE, Posner MR and TAX 324 Study Group: Induction chemotherapy with cisplatin and fluorouracil alone or in combination with docetaxel in locally advanced squamous-cell cancer of the head and neck: long-term results of the TAX 324 randomised phase 3 trial. Lancet Oncol 12: 153-159, 2011.

8. Iwao-Koizumi K, Matoba R, Ueno N, Kim SJ, Ando A, Miyoshi Y, Maeda E, Noguchi S and Kato K: Prediction of docetaxel response in human breast cancer by gene expression profiling. J Clin Oncol 20: 422-431, 2005. 
9. Holmgren A: Thioredoxin. Annu Rev Biochem 54: 237-271, 1985.

10. Miyazaki K, Noda N, Okada S, Hagiwara Y, Miyata M Sakurabayashi I, Yamaguchi N, Sugimura T, Terada M and Wakasugi H: Elevated serum level of thioredoxin in patients with hepatocellular carcinoma. Biotherapy 11: 277-288, 1998.

11. Nakamura H, Bai J, Nishinaka Y, Ueda S, Sasada T, Ohshio G, Imamura M, Takabayashi A, Yamaoka Y and Yodoi J: Expression of thioredoxin and glutaredoxin, redox-regulating proteins, in pancreatic cancer. Cancer Detect Prev 24: 53-60, 2000

12. Grogan TM, Fenoglio-Prieser C, Zeheb R, Bellamy W, Frutiger Y, Vela E, Stemmerman G, Macdonald J, Richter L, Gallegos A and Powis G: Thioredoxin, a putative oncogene product, is overexpressed in gastric carcinoma and associated with increased proliferation and increased cell survival. Hum Pathol 31: 475-481, 2000.

13. Kakolyris S, Giatromanolaki A, Koukourakis M, Powis G, Souglakos J, Sivridis E, Georgoulias V, Gatter KC and Harris AL: Thioredoxin expression is associated with lymph node status and prognosis in early operable non-small cell lung cancer. Clin Cancer Res 7: 3087-3091, 2001.

14. Raffel J, Bhattacharyya AK, Gallegos A, Cui H, Einspahr JG, Alberts DS and Powis G: Increased expression of thioredoxin-1 in human colorectal cancer is associated with decreased patient survival. J Lab Clin Med 142: 46-51, 2003.

15. Kim SJ, Miyoshi Y, Taguchi T, Tamaki Y, Nakamura H, Yodoi J, Kato K and Noguchi S: High thioredoxin expression is associated with resistance to docetaxel in primary breast cancer. Clin Cancer Res 11: 8425-8430, 2005.

16. Mitani T, Hoshikawa H, Mori T, Hosokawa T, Tsukamoto I, Yamaguchi F, Kamitori K, Tokuda M and Mori N: Growth inhibition of head and neck carcinomas by D-allose. Head Neck 31: 1049-1055, 2009.

17. Hoshikawa $\mathrm{H}$, Indo K, Mori $\mathrm{T}$ and Mori N: Mori, enhancement of the radiation effects by D-allose in head and neck cancer cells. Cancer Lett 306: 60-66, 2011.

18. Chung JW, Jeon JH, Yoon SR and Choi I: Vitamin D3 upregulated protein 1 (VDUP1) is a regulator for redox signaling and stress-mediated diseases. J Dermatol 33: 662-669, 2006.

19. Han SH, Jeon JH, Ju HR, Jung U, Kim KY, Yoo HS, Lee YH, Song KS, Hwang HM, Na YS, Yang Y, Lee KN and Choi I: VDUP1 upregulated by TGF-betal and 1,25-dihydorxyvitamin D3 inhibits tumor cell growth by blocking cell-cycle progression. Oncogene 22: 4035-4046, 2003.

20. Ohta S, Lai EW, Pang AL, Brouwers FM, Chan WY, Eisenhofer G, de Krijger R, Ksinantova L, Breza J, Blazicek P, Kvetnansky R, Wesley RA and Pacak K: Downregulation of metastasis suppressor genes in malignant pheochromocytoma. Int J Cancer 114: 139-143, 2005.

21. Butler LM, Zhou X, Xu WS, Scher HI, Rifkind RA, Marks PA and Richon VM: The histone deacetylase inhibitor SAHA arrests cancer cell growth, up-regulates thioredoxin-binding protein-2, and down-regulates thioredoxin. Proc Natl Acad Sci USA 99: 11700-11705, 2002.

22. Ikarashi M, Takahashi $Y$, Ishii $Y$, Nagata $T$, Asai $S$ and Ishikawa K: Vitamin D3 up-regulated protein 1 (VDUPI) expression in gastrointestinal cancer and its relation to stage of disease. Anticancer Res 22: 4045-4048, 2002.

23. de Vos S, Hofmann WK, Grogan TM, Krug U, Schrage M, Miller TP, Braun JG, Wachsman W, Koeffler HP and Said JW: Gene expression profile of serial samples of transformed B-cell lymphomas. Lab Invest 83: 271-285, 2003.
24. Haldar S, Basu A and Croce CM: Bcl2 is the guardian of microtubule integrity. Cancer Res 57: 229-233, 1997.

25. Naha N, Lee HY, Jo MJ, Chung BC, Kim SH and Kim MO: Rare sugar D-allose induces programmed cell death in hormone refractory prostate cancer cells. Apoptosis 13: 1121-1134, 2008.

26. Pradier O, Rave-Fränk M, Lehmann J, Lücke E, Boghun O, Hess CF and Schmidberger H: Effects of docetaxel in combination with radiation on human head and neck cancer cells (ZMK-1) and cervical squamous cell carcinoma cells (CaSki). Int J Cancer 91: 840-845, 2001

27. Mason KA, Kishi K, Hunter N, Buchmiller L, Akimoto T, Komaki R and Milas L: Effect of docetaxel on the therapeutic ratio of fractionated radiotherapy in vivo. Clin Cancer Res 5: 4191-4198, 1999

28. Mizumachi T, Suzuki S, Naito A, Carcel-Trullols J, Evans TT, Spring PM, Oridate N, Furuta Y, Fukuda S and Higuchi M: Increased mitochondrial DNA induces acquired docetaxel resistance in head and neck cancer cells. Oncogene 27: 831-838, 2008.

29. Khan IA and Ludueña RF: Possible regulation of the in vitro assembly of bovine brain tubulin by the bovine thioredoxin system. Biochim Biophys Acta 1076: 289-297, 1991.

30. Hirose K, Longo DL, Oppenheim JJ and Matsushima K: Overexpression of mitochondrial manganese superoxide dismutase promotes the survival of tumor cells exposed to interleukin-1, tumor necrosis factor, selected anticancer drugs, and ionizing radiation. FASEB J 7: 361-368, 1993.

31. Lee HC, Kim DW, Jung KY, Park IC, Park MJ, Kim MS, Woo SH, Rhee $\mathrm{CH}$, Yoo H, Lee SH and Hong SI: Increased expression of antioxidant enzymes in radioresistant variant from U251 human glioblastoma cell line. Int J Mol Med 13: 883-887, 2004.

32. Mirkovic N, Voehringer DW, Story MD, McConkey DJ, McDonnell TJ and Meyn RE: Resistance to radiation-induced apoptosis in Bcl-2-expressing cells is reversed by depleting cellular thiols. Oncogene 15: 1461-1470, 1997.

33. Sun J, Chen Y, Li M and Ge Z: Role of antioxidant enzymes on ionizing radiation resistance. Free Rad Biol Med 24: 586-593, 1998.

34. Furuse S, Adachi M, Ijichi K, Ohta S, Torigoe S, Nakazawa M, Miura S, Mitsudo K and Tohnai I: Pre-radiation enhances the cytotoxicity of docetaxel in head and neck squamous cell carcinoma cells. Oncol Rep 23: 1339-1343, 2010.

35. Yamaguchi F, Takata M, Kamitori K, Nonaka M, Dong Y, Sui L and Tokuda M: Rare sugar D-allose induces specific up-regulation of TXNIP and subsequent G1 cell cycle arrest in hepatocellular carcinoma cells by stabilization of p27kip1. Int J Oncol 32: 377-385, 2008.

36. Hoshikawa H, Mori T and Mori N: In vitro and in vivo effects of D-allose: up-regulation of thioredoxin-interacting protein in head and neck cancer cells. Ann Otol Rhinol Laryngol 119: 567-571, 2010.

37. Adachi I, Watanabe T, Takashima S, Narabayashi M,Horikoshi N, Aoyama H and Taguchi T: A late phase II study of RP56976 (docetaxel) in patients with advanced or recurrent breast cancer. Br J Cancer 73: 210-216, 1996.

38. Hirooka K, Miyamoto O, Jinming P, Du Y, Itano T, Baba T, Tokuda $M$ and Shiraga F: Neuroprotective effects of D-allose against retinal ischemia-reperfusion injury. Invest Ophthalmol Vis Sci 47: 1653-1657, 2006.

39. Mizote M, Hirooka K, Fukuda K, Nakamura T, Itano $T$ and Shiraga F: D-allose as ischemic retina injury inhibitor during rabbit vitrectomy. Jpn J Ophthalmol 55: 294-300, 2011. 